\title{
INTRACELLULAR FREE CALCIUM ACCUMULATION IN FERRET VASCULAR SMOOTH MUSCLE DURING CRYSTALLOID AND BLOOD CARDIOPLEGIC INFUSIONS
}

Motohisa Tofukuji, $\mathrm{MD}, \mathrm{PhD}^{\mathrm{a}}$ Naruto Matsuda, MD, $\mathrm{PhD}^{\mathrm{a}}$

Chantal Dessy, $\mathrm{PhD}^{\mathrm{b}}$

Kathleen G. Morgan, $\mathrm{PhD}^{\mathrm{b}}$

Frank W. Sellke, MD
Objective: The effects of magnesium- and potassium-based crystalloid and blood-containing cardioplegic solutions on coronary smooth muscle intracellular free calcium $\left(\left[\mathrm{Ca}^{2+}\right]_{\mathrm{i}}\right)$ accumulation and microvascular contractile function were examined. Methods: Isolated ferret hearts were subjected to hyperkalemic $\left(25 \mathrm{mmol} / \mathrm{L} \mathrm{K}^{+}\right)$blood cardioplegic infusion, hypermagnesemic ( $25 \mathrm{mmol} / \mathrm{L} \mathrm{Mg}^{2+}, \mathrm{K}^{+}$-free) crystalloid cardioplegic infusion, or hyperkalemic crystalloid cardioplegic infusion for 1 hour. Coronary arterioles were isolated, cannulated, and loaded with fura 2. Reactivity and $\left[\mathrm{Ca}^{2+}\right]_{i}$ were assessed with videomicroscopy. $\left[\mathrm{Ca}^{2+}\right]_{i}$ was measured at baseline and after application of $50 \mathrm{mmol} / \mathrm{L} \mathrm{KCl}$. In addition, $\left[\mathrm{Ca}^{2+}\right]_{\mathrm{i}}$ and vascular contraction were measured during exposure to $\mathrm{Mg}^{2+}$ and $\mathrm{K}^{+}$cardioplegic solution at both $4^{\circ} \mathrm{C}$ and $37^{\circ} \mathrm{C}$. Results: From a baseline $\left[\mathrm{Ca}^{2+}\right]_{\mathrm{i}}$ of $177 \pm 52 \mathrm{nmol} / \mathrm{L}, \mathrm{K}^{+}$cardioplegic infusion $(302 \pm 80$ $\mathrm{nmol} / \mathrm{L}$ potassium) markedly increased $\left[\mathrm{Ca}^{2+}\right]_{\mathrm{i}}$, whereas blood cardioplegic infusion (214 $\pm 53 \mathrm{nmol} / \mathrm{L})$ and $\mathrm{Mg}^{2+}$ cardioplegic infusion (180 \pm $42 \mathrm{nmol} / \mathrm{L}$ ) did not alter $\left[\mathrm{Ca}^{2+}\right]_{\mathrm{i}}$. Although a difference between groups in percentage contraction after application of $50 \mathrm{mmol} / \mathrm{L} \mathrm{KCl}$ was not observed, $\left[\mathrm{Ca}^{2+}\right]_{\mathrm{i}}$ increased significantly more in vessels in the control group $(764 \pm 327 \mathrm{nmol} / \mathrm{L})$ and the $\mathrm{K}^{+}$crystalloid cardioplegic infusion group $(698 \pm 215 \mathrm{nmol} / \mathrm{L})$ than in vessels in the blood cardioplegic infusion group (402 $\pm 45 \mathrm{nmol} / \mathrm{L})$ and the $\mathrm{Mg}^{2+}$ cardioplegic infusion group $(389 \pm 80 \mathrm{nmol} / \mathrm{L}) \cdot \mathrm{Mg}^{2+}$ cardioplegic solution induced no microvascular contraction at either $4^{\circ} \mathrm{C}$ or $37^{\circ} \mathrm{C}$, nor was an increase in $\left[\mathrm{Ca}^{2+}\right]_{\mathrm{i}}$ observed. $\mathrm{K}^{+}$cardioplegic solution induced microvascular contraction at $37^{\circ} \mathrm{C}$ but not at $4^{\circ} \mathrm{C}$; it increased $\left[\mathrm{Ca}^{2+}\right]_{\mathrm{i}}$ at both $4^{\circ} \mathrm{C}$ and $37^{\circ} \mathrm{C}$. Conclusion: An $\mathrm{Mg}^{2+}$-based cardioplegic solution, or appropriate $\mathrm{Mg}^{2+}$ or blood supplementation of a $\mathrm{K}^{+}$crystalloid cardioplegic solution, may decrease the accumulation of $\left[\mathrm{Ca}^{2+}\right]_{i}$ in the vascular smooth muscle during ischemic arrest. (J Thorac Cardiovasc Surg 1999;118:163-72) ntracellular calcium $\left[\mathrm{Ca}^{2+}\right]_{\mathrm{i}}$ accumulation in coronary smooth muscle cells is associated with derangements in coronary vasomotor tone and contractility after ischemic cardioplegic infusion. The altered myogenic

From the Division of Cardiothoracic Surgery, Department of Surgery, Beth Israel Deaconess Medical Center and Harvard Medical School, ${ }^{\mathrm{a}}$ and Boston Biomedical Research Institute, ${ }^{\mathrm{b}}$ Boston.

Supported by the National Institutes of Health grants HL46716 (F.W.S.) and HL31704 (K.G.M.).

Received for publication Nov 9, 1998; revisions requested Feb 5, 1999; revisions received Feb 25, 1999; accepted for publication March 8, 1999.

Address for reprints: Frank W. Sellke, MD, Division of Cardiothoracic Surgery, Beth Israel Deaconess Medical Center, Dana 905, 330 Brookline Ave, Boston, MA 02215.

Copyright (C) 1999 by Mosby, Inc.

$0022-5223 / 99 \$ 8.00+0 \quad \mathbf{1 2 / 1 / 9 8 4 3 1}$ contraction during and after potassium cardioplegic infusion is in part associated with opening of adenosine triphosphate-activated potassium channels $\left(\mathrm{K}^{+}{ }_{\text {ATP }}\right.$ channels) and calcium accumulation in the coronary vascular smooth muscle. ${ }^{1,2}$ The inhibition of accumulation of $\left[\mathrm{Ca}^{2+}\right]_{\mathrm{i}}$ and maintenance of ATP tissue concentration with magnesium or other substances may theoretically favor a magnesium-based or blood-based cardioplegic solution. ${ }^{3}$ Because the addition of blood to potassium cardioplegic solution ${ }^{4}$ and magnesium cardioplegic solution $^{2}$ have similar effects in preserving $\beta$-adrenergic and endothelium-dependent relaxation and myogenic contraction, all of which are important in blood flow regulation, it was hypothesized that the addition of blood or $\mathrm{Mg}^{2+}$ to a hyperkalemic crystalloid cardioplegic solution could prevent functional damage to the vascular 
system caused by increased $\left[\mathrm{Ca}^{2+}\right]_{\mathrm{i}}$ accumulation in the coronary smooth muscle. In this study $\left[\mathrm{Ca}^{2+}\right]_{\mathrm{i}}$ accumulation in the coronary vascular smooth muscle and microvascular contraction were examined during ischemic arrest with a cold hyperkalemic blood cardioplegic solution, a hyperkalemic crystalloid cardioplegic solution, or a magnesium-based cardioplegic solution. Because the coronary microcirculation is the primary site of regulation of myocardial perfusion, microvascular tissue was examined.

\section{Materials and methods}

Male ferrets (8-12 weeks of age) were anesthetized with chloroform in a ventilation hood. The hearts were removed after injection of a small amount of heparin and were immediately immersed in a cold $\left(4^{\circ} \mathrm{C}\right)$ saline solution. The following procedures were immediately undertaken.

Crystalloid cardioplegic infusion groups. After the cannulation of the ascending aortic root of isolated ferret hearts with a small catheter, $20 \mathrm{~mL}$ cold $\left(4^{\circ} \mathrm{C}\right) \mathrm{Ca}^{2+}$-free hypermagnesemic crystalloid cardioplegic solution $\left(25 \mathrm{mmol} / \mathrm{L} \mathrm{Mg}^{2+}\right.$, $\mathrm{n}=6$ ) or cold $\mathrm{Ca}^{2+}$-free hyperkalemic crystalloid cardioplegic solution ( $25 \mathrm{mmol} / \mathrm{L} \mathrm{K}^{+}, \mathrm{n}=6$ ) was infused into the coronary arteries through the aorta at a pressure of approximately 40 $\mathrm{mm} \mathrm{Hg}$. The composition of the $\mathrm{Mg}^{2+}$ cold crystalloid cardioplegic solution was as follows (in millimoles per liter): 121.0 $\mathrm{NaCl}, 25.0 \mathrm{MgCl}_{2}, 4.7 \mathrm{KCl}, 12.0 \mathrm{NaHCO}_{3}$, and 11.1 glucose in purified water. $\mathrm{K}^{+}$cold crystalloid cardioplegic solution had the following composition (in millimoles per liter): $121.0 \mathrm{NaCl}, 25.0 \mathrm{KCl}, 12.0 \mathrm{NaHCO}_{3}$, and $11.1 \mathrm{mmol} / \mathrm{L}$ glucose in purified water. In both groups saline solution slush was placed on the surface of the heart to provide topical hypothermia during the ischemic period. Infusion of the cardioplegic solution $(10 \mathrm{~mL})$ in each group was repeated at 20minute intervals for a total arrest time of 60 minutes ( 2 additional doses). The heart was then immediately placed in a cold Krebs buffer solution of the following composition (in millimoles per liter): $118.3 \mathrm{NaCl}, 4.7 \mathrm{KCl}, 2.5 \mathrm{CaCl}_{2}, 1.2$ $\mathrm{MgSO}_{4}, 1.2 \mathrm{NaH}_{2} \mathrm{PO}_{4}, 25.0 \mathrm{NaHCO}_{3}$, and 11.1 glucose in purified water.

Blood cardioplegic infusion group. In 6 isolated ferret hearts, $20 \mathrm{~mL}$ hyperkalemic cold blood cardioplegic solution (4:1 mixture of oxygenated blood with high-potassium crystalloid cardioplegic solution resulting in $25 \mathrm{mmol} / \mathrm{L} \mathrm{KCl}$ ) was infused into the aortic root as described above previously, followed by intermittent infusion of $10 \mathrm{~mL}$ low-potassium cold blood cardioplegic solution (4:1 mixture of oxygenated blood with low-potassium crystalloid cardioplegic solution resulting in $12.5 \mathrm{mmol} / \mathrm{L} \mathrm{KCl})$ every 20 minutes $\left(\mathrm{K}^{+}\right.$blood cardioplegic infusion group). The compositions of the high- and low-potassium solutions used in this study to create the blood cardioplegic solutions contained 60 or $30 \mathrm{mmol} / \mathrm{L} \mathrm{KCl}$, respectively, $12.5 \mathrm{~g}$ mannitol, $50 \mathrm{~mL}$ citrate-phosphate-dextrose solution and $10 \mathrm{mEq}$ tris(hydroxymethyl)aminomethane in $500 \mathrm{~mL}$ of $5 \%$ dextrose and $0.225 \%$ saline solution. In all groups, after 60 minutes of cardioplegic arrest the heart was immediately placed in a cold Krebs buffer solution.

Cold global ischemia group. In another 6 experiments isolated ferret hearts were flushed with cold Krebs buffer solution, placed in a cold saline solution for 60 minutes (cold global ischemia group) and then placed in a cold Krebs buffer solution.

Animal care. All animals received humane care in compliance with the Boston Biomedical Research Institute Committee on Animal Research and the "Guide for the Care and Use of Laboratory Animals" prepared by the Institute of Laboratory Animal Resources and published by the National Institute of Health (NIH Publication No. 86-23, revised 1985).

Responses of nonischemic vessels. Microvessels were immediately obtained from nonischemic ferret hearts, cannulated as described previously, and then loaded with fura 2. Vessels were exposed to either $\mathrm{Mg}^{2+}$ cold crystalloid cardioplegic solution, $\mathrm{Mg}^{2+}$ cold crystalloid cardioplegic solution supplemented with $1.0 \mathrm{mmol} / \mathrm{L} \mathrm{Ca}^{2+}$ cold crystalloid cardioplegic solution, $\mathrm{K}^{+}$cold crystalloid cardioplegic solution supplemented with $1.0 \mathrm{mmol} / \mathrm{L} \mathrm{Ca}^{2+}$, or $\mathrm{K}^{+}$cold crystalloid cardioplegic solution supplemented with $1.0 \mathrm{mmol} / \mathrm{L} \mathrm{Mg}^{2+}$ at either $4^{\circ} \mathrm{C}$ or $37^{\circ} \mathrm{C}$ ( $\mathrm{n}=4-5$ hearts/group) for 5 to 10 minutes. The fluorescence and contraction responses were then measured.

Coronary microvessel preparations. After ischemic cardioplegic interventions, coronary arterioles (mean $133 \pm 8$ $\mu \mathrm{m}$ in internal diameter, ranging from 100 to $150 \mu \mathrm{m}$ ) were immediately dissected from the left anterior descending coronary artery-dependent subepicardial region of the free wall of the left ventricle with $\mathrm{a} \times 10$ to $\times 60$ dissecting microscope (Olympus Optical Co, Ltd, Tokyo, Japan). The vessels were placed in a microvessel chamber (University of Iowa Medical Instrumentation, Iowa City, Iowa), cannulated with dual glass micropipettes measuring 40 to $80 \mu \mathrm{m}$ in diameter, and secured with 10-0 nylon monofilament suture (Ethicon, Inc, Somerville, NJ). Oxygenated (95\% oxygen and 5\% carbon dioxide) Krebs buffer solution warmed to $37^{\circ} \mathrm{C}$ was continuously circulated through the microvessel chamber. Vessels were pressurized to $40 \mathrm{~mm} \mathrm{Hg}$ in a no-flow state by means of a burette manometer filled with a Krebs buffer solution. With an inverted microscope (Zeiss IM 35, ×40-200; Carl Zeiss, Inc, Thornwood, NY) connected to a camera (Hitachi model KP 115; Hitachi Denshi America, Ltd, Woodbury, NY), the microvessel image was projected onto a black and white television monitor. The microvessels were allowed to bathe in the chamber for at least 30 minutes before internal lumen diameter and $\left[\mathrm{Ca}^{2+}\right]_{\mathrm{i}}$ measurements were taken at baseline and under various conditions.

Coronary smooth muscle $\left[\mathrm{Ca}^{2+}\right]_{i}$ handling and concentration. Vascular smooth muscle $\left[\mathrm{Ca}^{2+}\right]_{\mathrm{i}}$ was measured in isolated single coronary microvessels as previously reported by Meininger and colleagues. ${ }^{5}$ In $\mathrm{K}^{+}$blood cardioplegic infusion, $\mathrm{Mg}^{2+}$ cold crystalloid cardioplegic infusion, $\mathrm{K}^{+}$cold crystalloid cardioplegic infusion, and cold global ischemia groups, after equilibration of the microvessels, fura 2 was loaded into the microvessels with a noncirculating Krebs solution containing $5 \mu \mathrm{mol} / \mathrm{L}$ fura $2 \mathrm{AM}$, which was dis- 
solved in $0.05 \%$ dimethyl sulfoxide and $0.01 \%$ pluronic acid at room temperature $\left(22^{\circ} \mathrm{C}-25^{\circ} \mathrm{C}\right)$, for 45 minutes. At the end of the loading period the extracellular fura $2 \mathrm{AM}$ was washed out with Krebs solution and at least 30 minutes was allowed for de-esterification of intracellular fura $2 \mathrm{AM}$ at $37^{\circ} \mathrm{C}$. Fura 2 signals from the microvessels were recorded by positioning the pinhole on the lowest and most homogeneous location of the microvessel wall with a Nikon Fluor $\times 40$ (NA 0.8; Nikon Corporation, Tokyo, Japan) objective. To minimize bleaching and cell damage, the shutter was opened only when necessary for taking measurements. Excitation interference filters at $350 \pm 5 \mathrm{~nm}$ and $390 \pm 6 \mathrm{~nm}$ were used.

A computer-controlled filter wheel produced by Ludl switches filtered every 2 msec. Fluorescent signals were collected with a photomultiplier tube (Hamamatsu R928; Hamamatsu Photonics KK, Hananatsu City, Japan) after excitation at $350 \mathrm{~nm}$ and $390 \mathrm{~nm}$. The signals at the 2 wavelengths from the photomultiplier tube were digitized by a Data Acquisition-EZ A/D Converter and processed using a DTVee program version 3.0 (Data Translation, Inc, Marlboro, Mass). The background signals at the 2 wavelengths were measured to subtract from subsequent fluorescent signal measurements. Baseline and $\mathrm{KCl}$-induced $(50 \mathrm{mmol} / \mathrm{L})$ $\left[\mathrm{Ca}^{2+}\right]_{\mathrm{i}}$ changes in fluorescence at 350 and $390 \mathrm{~nm}$ were recorded at steady-state at the same time that the respective contraction responses were observed. A $50-\mathrm{mmol} / \mathrm{L} \mathrm{KCl} \mathrm{con-}$ centration was chosen to induce an increase in $\left[\mathrm{Ca}^{2+}\right]_{i}$. Measurements were made and recorded 3 to 5 minutes after the drug administration, when the response had stabilized. The microvessels were washed with Krebs buffer solution at $37^{\circ} \mathrm{C}$ and allowed to equilibrate in a drug-free Krebs buffer solution for 20 minutes between interventions. Comparisons were made against the responses of microvessels and $\left[\mathrm{Ca}^{2+}\right]_{\mathrm{i}}$ from instrument-free control hearts.

Absolute $\left(\left[\mathrm{Ca}^{+2}\right]_{\mathrm{i}}\right)$ was calculated as follows:

$$
\left[\mathrm{Ca}^{+2}\right]_{\mathrm{i}}=\mathrm{K}_{\mathrm{d}} \times\left[\left(\mathrm{R}-\mathrm{R}_{\min }\right) /\left(\mathrm{R}_{\max }-\mathrm{R}\right)\right] \times \mathrm{S}
$$

where $\mathrm{K}_{\mathrm{d}}$ was the dissociation constant; $R$ was the ratio of the smooth muscle signal at $350 \mathrm{~nm}$ to that at $390 \mathrm{~nm}$; Rmax was determined after treating microvessels with $50 \mu \mathrm{mol} / \mathrm{L} \mathrm{4-}$ bromo-A23187 containing $150 \mathrm{mmol} / \mathrm{L} \mathrm{KCl}, 1 \mathrm{mmol} / \mathrm{L} \mathrm{Ca}^{2+}$, and $5 \mathrm{mmol} / \mathrm{L}$ piperazine- $N$ - $N{ }^{\prime}$-bis (2-ethanesulfonic acid) (PIPES); Rmin was determined after treating microvessels with $4 \mathrm{mmol} / \mathrm{L}$ ethyleneglycol-bis-( $\beta$-aminoethylether)$N, N, N^{\prime}, N^{\prime}$-tetraacetic acid; and $S$ was the ratio of the $390 \mathrm{~nm}$ signal in microvessels treated with ethyleneglycol-bis-( $\beta$ aminoethylether)- $N, N, N^{\prime}, N^{\prime}$-tetraacetic acid to that in the presence of 4-bromo-A23187. A $\mathrm{K}_{\mathrm{d}}$ value of $240 \mathrm{nmol} / \mathrm{L}$ at $37^{\circ} \mathrm{C}$ was used. The increase in absolute $\left[\mathrm{Ca}^{2+}\right]_{\mathrm{i}}$ was expressed as percentage change from baseline $\left[\mathrm{Ca}^{2+}\right]_{\mathrm{i}}(100 \%$ $\times$ given $\left[\mathrm{Ca}^{2+}\right]_{\mathrm{i}} /$ baseline $\left[\mathrm{Ca}^{2+}\right]_{\mathrm{I}}$ ).

Drugs. Fura 2 AM was obtained from Molecular Probes (Molecular Probes, Inc, Eugene, Ore). The 4-bromo-A23187 and dimethyl sulfoxide were Calbiochem brand $(\mathrm{CN}$ Biosciences, Inc, San Diego, Calif). Ethyleneglycol-bis-( $\beta$ aminoethylether)- $N, N, N^{\prime}, N^{\prime}$-tetraacetic acid, PIPES, magnesium chloride and pluronic acid were obtained from Sigma
(Sigma, St Louis, Mo). KCl were obtained from Fisher Scientific (Fisher Scientific Worldwide, Laboratory Projects Division, Springfield, NJ). Pluronic acid was dissolved in dimethyl sulfoxide to make a stock solution that was stored at $-20^{\circ} \mathrm{C}$. Fura $2 \mathrm{AM}$ solution was prepared on the day of the study. Other drugs were dissolved in ultrapure distilled water.

Statistical analysis. The contraction responses were expressed as the percentage contraction of the initial diameter of the microvessels. A negative value denoted relaxation response. All data were expressed as mean $\pm \mathrm{SD}$. Analysis of variance followed by the Fisher exact test was used to compare changes in percentage increase or absolute change in $\left[\mathrm{Ca}^{2+}\right]_{i}$ between groups or to compare percentage vascular contraction between groups. Depending on the number of multiple comparisons performed, the Bonferroni correction was used to correct for multiple comparisons.

\section{Results}

Effects of ischemic cardioplegic infusion. Although exposure of microvessels to cold $\mathrm{K}^{+}$crystalloid cardioplegic solution or cold global ischemia significantly increased $\left[\mathrm{Ca}^{2+}\right]_{\mathrm{i}}$, exposure to cold $\mathrm{K}^{+}$blood cardioplegic solution or cold $\mathrm{Mg}^{2+}$ crystalloid cardioplegic solution did not increase $\left[\mathrm{Ca}^{2+}\right]_{\mathrm{I}}$ (Fig 1). These changes in $\left[\mathrm{Ca}^{2+}\right]_{\mathrm{i}}$ were not completely reversible after repetitive washing with Krebs buffer solution at $37^{\circ} \mathrm{C}$ (data not shown).

No differences in percentage contraction were observed between groups after application of 50 $\mathrm{mmol} / \mathrm{L} \mathrm{KCl}$ (Fig 2). However, $\left[\mathrm{Ca}^{2+}\right]_{\mathrm{i}}$ in absolute terms increased significantly more in control vessels (764 $\pm 327 \mathrm{nmol} / \mathrm{L})$ and vessels in the $\mathrm{K}^{+}$cold crystalloid cardioplegic infusion group $(698 \pm 215 \mathrm{nmol} / \mathrm{L})$ than in microvessels in the $\mathrm{K}^{+}$blood cardioplegic infusion group $\left(402 \pm 45 \mathrm{nmol} / \mathrm{L}, P=.04\right.$ versus $\mathrm{K}^{+}$cold crystalloid cardioplegic infusion), $\mathrm{Mg}^{2+}$ cold crystalloid cardioplegic infusion $(389 \pm 80 \mathrm{nmol} / \mathrm{L}, P=.02$ versus $\mathrm{K}^{+}$cold crystalloid cardioplegic infusion), and cold global ischemia $(580 \pm 110 \mathrm{nmol} / \mathrm{L})$ groups. In terms relative to the baseline concentration, changes in $\left[\mathrm{Ca}^{2+}\right]_{\mathrm{i}}$ induced by $50 \mathrm{mmol} / \mathrm{L} \mathrm{KCl}$ were similar and significantly less than the increase observed in control vessels (Fig 3).

Responses of nonischemic vessels to cardioplegic solution. Direct exposure of isolated vessels to $\mathrm{K}^{+}$cold crystalloid cardioplegic solution at $4{ }^{\circ} \mathrm{C}$ increased $\left[\mathrm{Ca}^{2+}\right]_{\mathrm{i}}$ (Fig 4) and was associated with a small contraction (Fig 5). Exposure to $\mathrm{K}^{+}$cold crystalloid cardioplegic solution at $37^{\circ} \mathrm{C}$ increased microvascular $\left[\mathrm{Ca}^{2+}\right]_{\mathrm{i}}$ in a similar manner (Fig 4). However, this increase was associated with a significant contraction of the microvessels (Fig 5). The increase in $\left[\mathrm{Ca}^{2+}\right]_{i}$ was substantially reversible to the baseline value after 


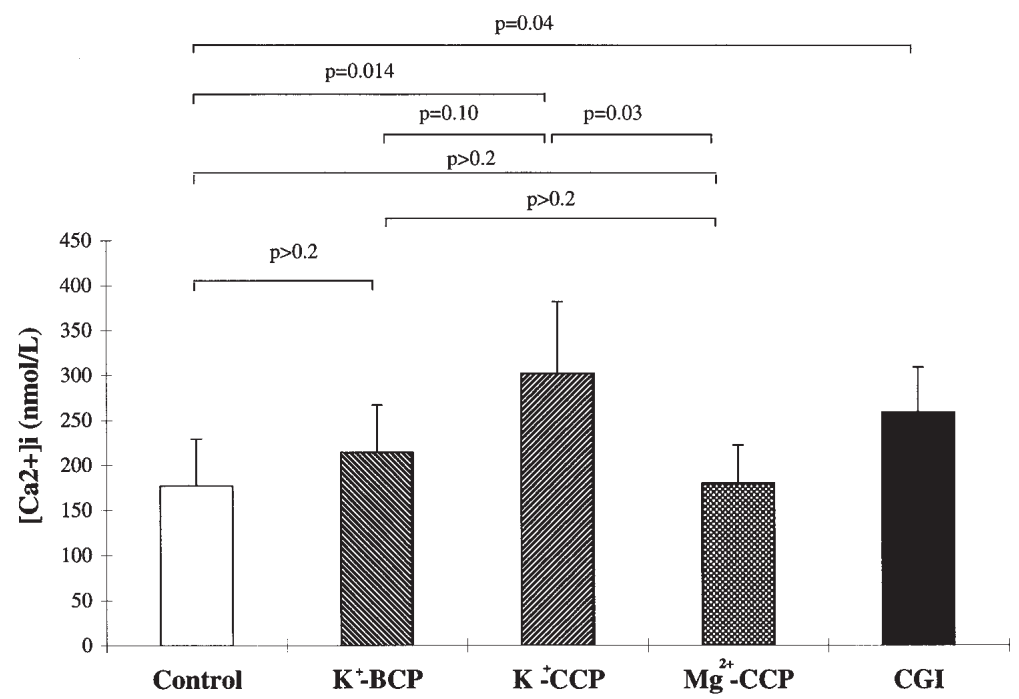

Fig 1. Coronary smooth muscle intracellular free calcium concentrations $\left(\left[\mathrm{Ca}^{2+}\right]_{i}\right)$ at baseline after 1 hour of cardioplegic infusion corresponding to ratios of fluorescence at $350 \mathrm{~nm}$ to that at $390 \mathrm{~nm}$ with fura2. $K^{+}-B C P$, Cold blood cardioplegic infusion; $\mathrm{K}^{+}-\mathrm{CCP}$, calcium-free hyperkalemic cardioplegic infusion; $\mathrm{Mg}^{2+}-C C P$, calcium freehypermagnesemic cardioplegic infusion; $C G I$, cold global ischemia. Boxes represent mean; error bars indicate $\mathrm{SD} ; \mathrm{n}=6$ for each group.

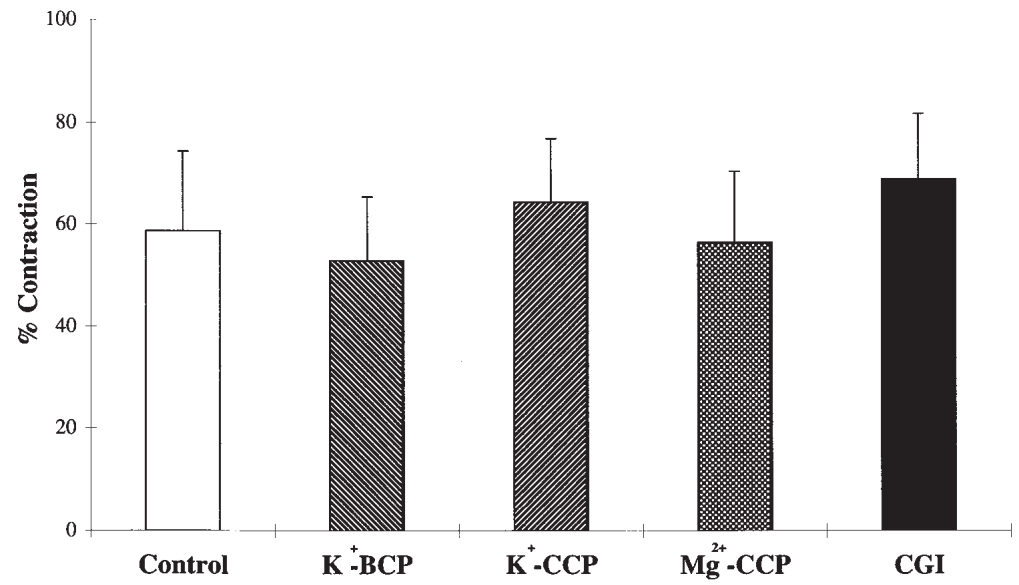

Fig 2. Percentage contraction of initial internal diameter of microvessels in response to application of $50 \mathrm{mmol} / \mathrm{L}$ potassium chloride after cardioplegic infusion. $K^{+}-B C P$, Cold blood cardioplegic infusion; $K^{+}-C C P$, calcium-free hyperkalemic cardioplegic infusion; $\mathrm{Mg}^{2+}-\mathrm{CCP}$, calcium-free hypermagnesemic cardioplegic infusion; $C G I$, cold global ischemia. Boxes represent mean; error bars indicate $\mathrm{SD} ; \mathrm{n}=6$ for each group.

repetitive washing with a Krebs buffer solution at $37^{\circ} \mathrm{C}$ but not at $4^{\circ} \mathrm{C}$ (data not shown). $\mathrm{Mg}^{2+}$ cold crystalloid cardioplegic solution induced no contraction of the nonischemic microvessels at either $4^{\circ} \mathrm{C}$ or $37^{\circ} \mathrm{C}(\mathrm{Fig}$ 4), nor did it increase $\left[\mathrm{Ca}^{2+}\right]_{\mathrm{i}}$ above the baseline value (Fig 5).

Effects of $\mathrm{Ca}^{2+}$ supplementation. The addition of $1.0 \mathrm{mmol} / \mathrm{L} \mathrm{Ca}^{2+}$ to $\mathrm{K}^{+}$cold crystalloid cardioplegic solution at $4{ }^{\circ} \mathrm{C}$ increased $\left[\mathrm{Ca}^{2+}\right]_{\mathrm{I}}$ (Fig 6) without caus- ing a significant contraction of the microvessels (Fig 7). At $37^{\circ} \mathrm{C}, \mathrm{K}^{+}$cold crystalloid cardioplegic solution with $1.0 \mathrm{mmol} / \mathrm{L} \mathrm{Ca}^{2+}$ increased $\left[\mathrm{Ca}^{2+}\right]_{i}$ similarly but in this case was associated with a significant contraction response of coronary microvessels (Figs 6 and 7). In contrast, $\mathrm{Mg}^{2+}$ cold crystalloid cardioplegic solution containing $1.0 \mathrm{mmol} / \mathrm{L} \mathrm{Ca}^{2+}$ at either $4^{\circ} \mathrm{C}$ or $37^{\circ} \mathrm{C}$ resulted in no increase in $\left[\mathrm{Ca}^{2+}\right]_{\mathrm{i}}$ (Fig 6), probably as a result of $\mathrm{Ca}-\mathrm{Mg}$ antagonism. No contraction of the 


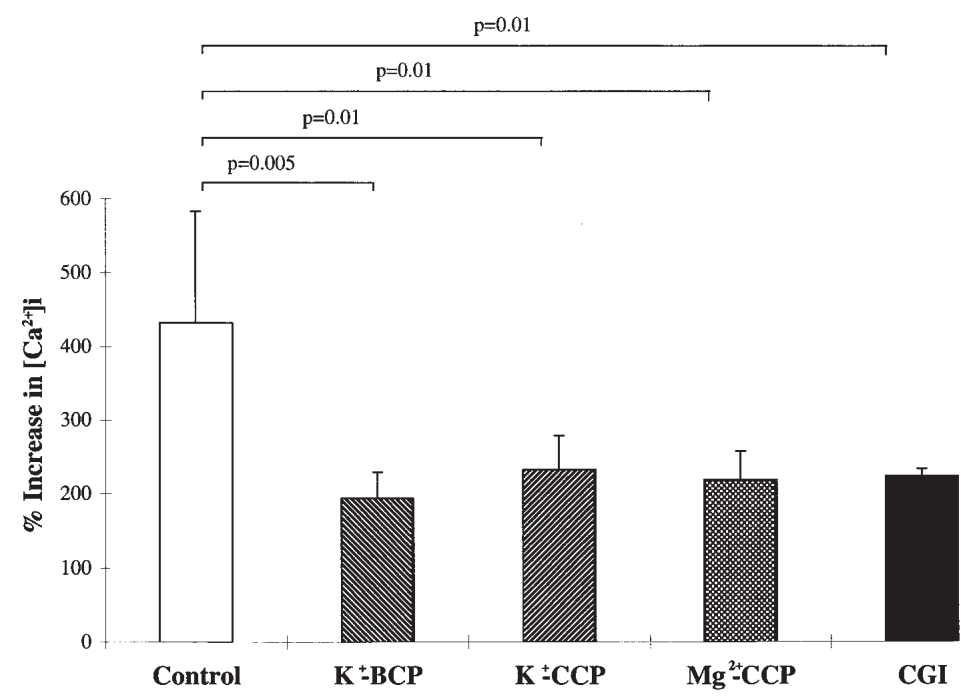

Fig 3. Percentage increase from baseline of intracellular free calcium concentration $\left(\left[\mathrm{Ca}^{2+}\right]_{i}\right)$ in response to application of $50 \mathrm{mmol} / \mathrm{L}$ potassium chloride after cardioplegic infusion. $K^{+}-B C P$, Cold blood cardioplegic infusion; $\mathrm{K}^{+}-\mathrm{CCP}$, calcium-free hyperkalemic cardioplegic infusion; $\mathrm{Mg}^{2+}-\mathrm{CCP}$, calcium free-hypermagnesemic cardioplegic infusion; CGI, cold global ischemia. Boxes represent mean; error bars indicate SD; $\mathrm{n}=6$ for each group.

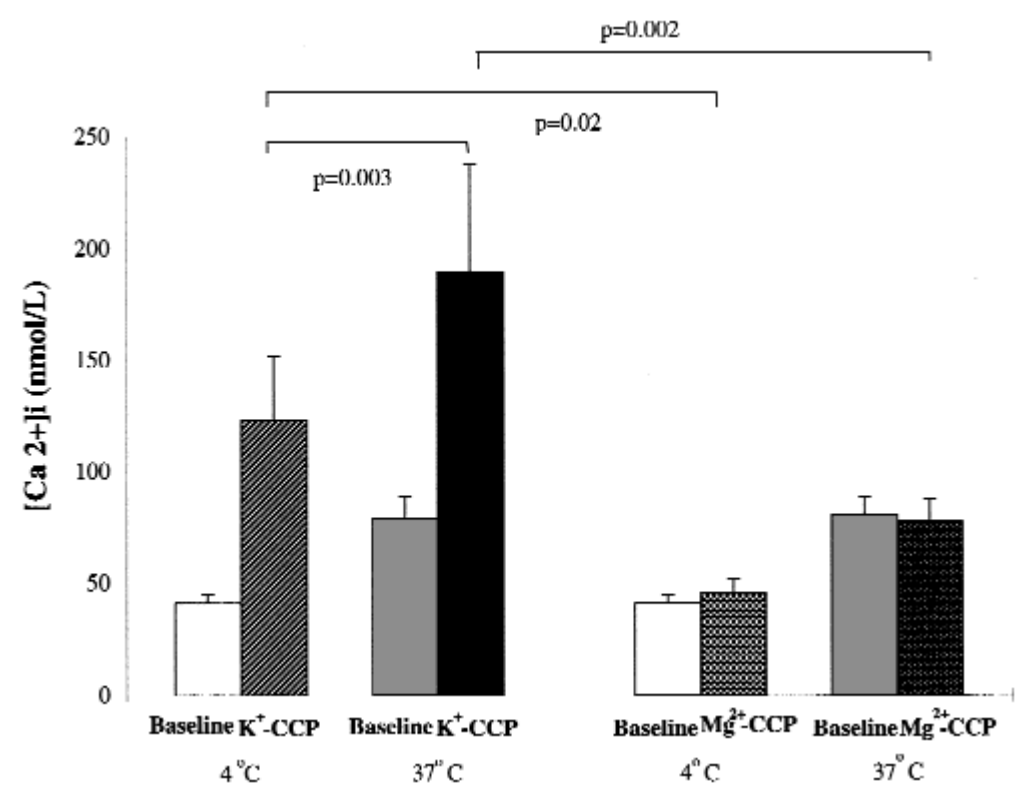

Fig 4. Percentage contraction of initial internal diameter of nonischemic microvessels in response to application of hyperkalemic crystalloid cardioplegic solution and calcium-free hypermagnesemic crystalloid cardioplegic solution at $4^{\circ} \mathrm{C}$ and $37^{\circ} \mathrm{C}$ in nonischemic microvessels. $K^{+}-C C P$, Calcium-free hyperkalemic cardioplegic solution; $\mathrm{Mg}^{2+}-\mathrm{CCP}$, calcium free-hypermagnesemic cardioplegic solution. Boxes represent mean; error bars indicate $\mathrm{SD} ; \mathrm{n}=4$ to 5 for each group.

microvessels was observed after exposure to $\mathrm{Mg}^{2+}$ cold crystalloid cardioplegic solution with $1.0 \mathrm{mmol} / \mathrm{L} \mathrm{Ca}^{2+}$ at either $4^{\circ} \mathrm{C}$ or $37^{\circ} \mathrm{C}$ (Fig 7).

Supplementation with $\mathrm{Mg}^{2+}$. Supplementation of $\mathrm{K}^{+}$cold crystalloid cardioplegic solution with 1.0 $\mathrm{mmol} / \mathrm{L} \mathrm{Mg}^{2+}$ was sufficient to inhibit the increase in $\left[\mathrm{Ca}^{2+}\right]_{\mathrm{i}}$ at $4^{\circ} \mathrm{C}$ but not at $37^{\circ} \mathrm{C}$ (Fig 8), suggesting that the minimum concentration of $\mathrm{Mg}^{2+}$ required to abolish the increase in $\left[\mathrm{Ca}^{2+}\right]_{\mathrm{i}}$ is temperature dependent ${ }^{6}$ and that a small increase in magnesium supplementa- 


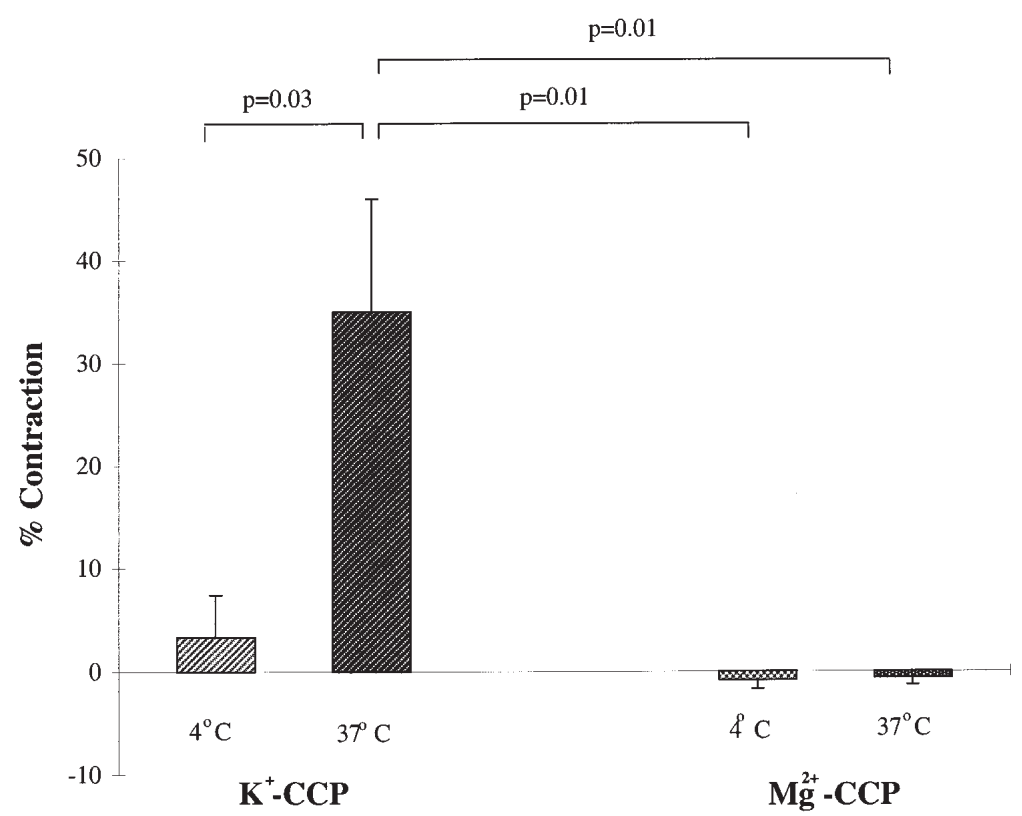

Fig 5. Increase from baseline in intracellular free calcium concentration $\left(\left[\mathrm{Ca}^{2+}\right]_{i}\right)$ in response to application of hyperkalemic crystalloid cardioplegic solution and hypermagnesemic crystalloid cardioplegic solution at $4^{\circ} \mathrm{C}$ and $37^{\circ} \mathrm{C}$ in nonischemic microvessels. $\mathrm{K}^{+}-\mathrm{CCP}$, Calcium-free hyperkalemic cardioplegic solution; $\mathrm{Mg}^{2+}-\mathrm{CCP}$, calcium-free hypermagnesemic cardioplegic solution. Boxes represent mean; error bars indicate SD; $\mathrm{n}=4$ to 5 for each group.

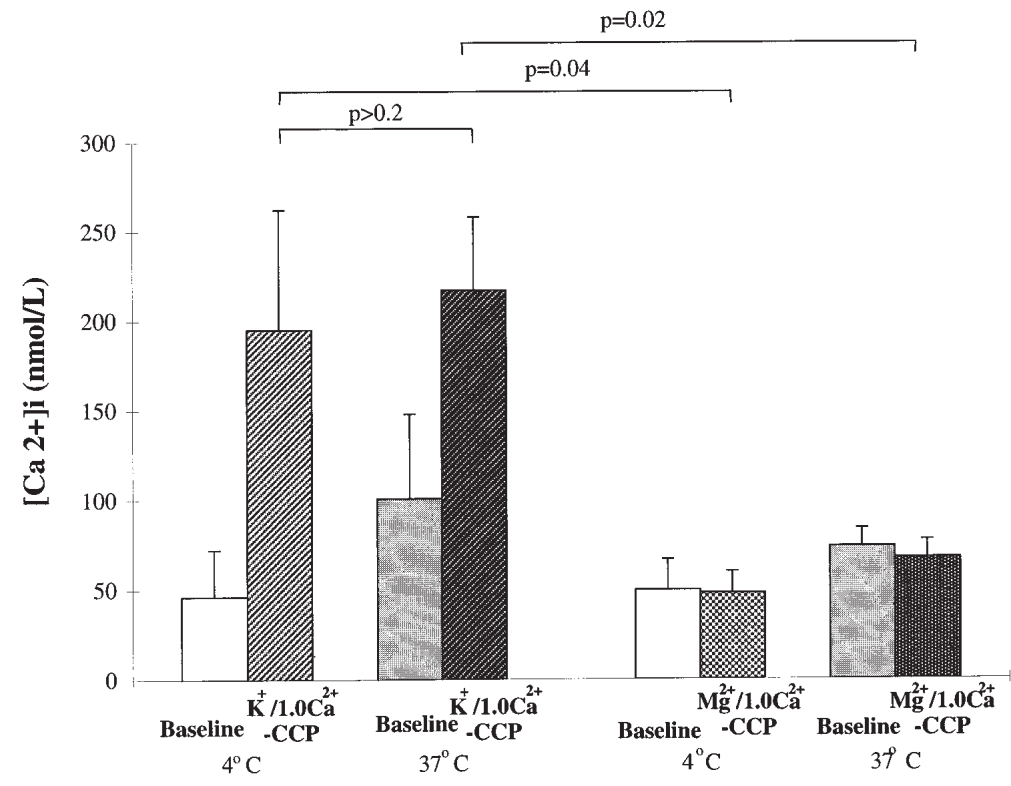

Fig 6. Increase from baseline in intracellular free calcium concentration $\left(\left[\mathrm{Ca}^{2+}\right]_{i}\right)$ after application of hyperkalemic crystalloid cardioplegic solution with $1.0 \mathrm{mmol} / \mathrm{L}$ calcium ion and hypermagnesemic crystalloid cardioplegic solution with 1.0 calcium ion at $4^{\circ} \mathrm{C}$ and $37^{\circ} \mathrm{C}$ in nonischemic microvessels. $\mathrm{K}^{+} / 1.0 \mathrm{Ca}^{2+}{ }_{-} \mathrm{CCP}$, Hyperkalemic cardioplegic solution containing $1.0 \mathrm{mmol} / \mathrm{L}$ calcium ion; $\mathrm{Mg}^{2+} / 1.0 \mathrm{Ca}^{2+} \mathrm{CCP}$, hypermagnesemic cardioplegic solution containing $1.0 \mathrm{mmol} / \mathrm{L}$ calcium ion. Boxes represent mean; error bars indicate $\mathrm{SD} ; \mathrm{n}=4$ to 5 for each group. 


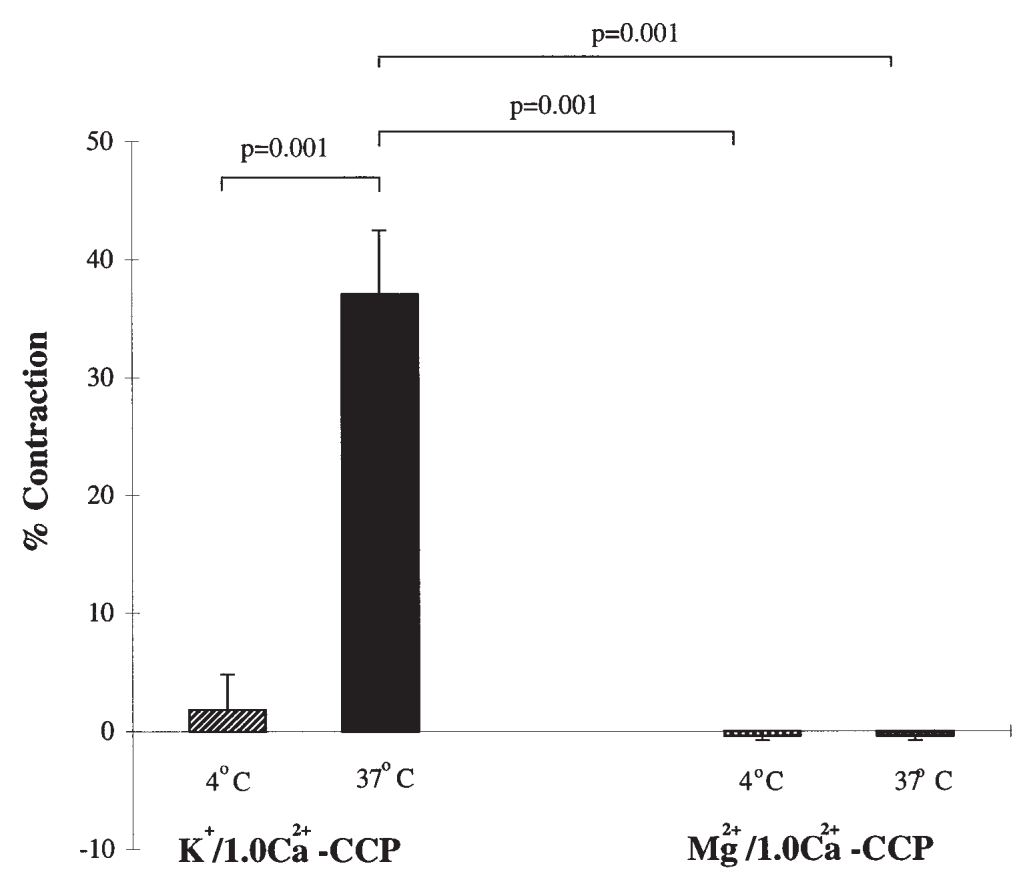

Fig 7. Percentage contraction of initial internal diameter of nonischemic microvessels after application of hyperkalemic crystalloid cardioplegic solution with $1.0 \mathrm{mmol} / \mathrm{L}$ calcium ion and hypermagnesemic crystalloid cardioplegic solution with $1.0 \mathrm{mmol} / \mathrm{L}$ calcium ion at $4^{\circ} \mathrm{C}$ and $37^{\circ} \mathrm{C}$ in nonischemic microvessels. $\mathrm{K}^{+} / 1.0 \mathrm{Ca}^{2+}{ }_{-} \mathrm{CCP}$, Hyperkalemic cardioplegic solution containing $1.0 \mathrm{mmol} / \mathrm{L}$ calcium ion; $\mathrm{Mg}^{2+} / 1.0 \mathrm{Ca}^{2+}-\mathrm{CCP}$, hypermagnesemic cardioplegic solution containing $1.0 \mathrm{mmol} / \mathrm{L}$ calcium ion. Boxes represent mean; error bars indicate $\mathrm{SD} ; \mathrm{n}=4$ to 5 for each group.

tion in a hypothermic solution may be sufficient to significantly inhibit the increase in $\left[\mathrm{Ca}^{2+}\right]_{i}$ during cardioplegic infusion. No significant contraction of microvessels was observed in response to exposure to $\mathrm{K}^{+}$cold crystalloid cardioplegic solution with $1.0 \mathrm{mmol} / \mathrm{L}$ $\mathrm{Mg}^{2+}\left(-2 \% \pm 1 \%\right.$ at both $4^{\circ} \mathrm{C}$ and $\left.37^{\circ} \mathrm{C}\right)$.

\section{Discussion}

Cold hyperkalemic crystalloid cardioplegic infusion caused an increase in $\left[\mathrm{Ca}^{2+}\right]_{\mathrm{i}}$ in the coronary microvascular smooth muscle similar to that observed during unprotected ischemia. Exposure of hearts to hypermagnesemic cardioplegic solution or the addition of $\mathrm{Mg}^{2+}$ or blood to a hyperkalemic cardioplegic solution attenuated the increase in microvascular $\left[\mathrm{Ca}^{2+}\right]_{\mathrm{i}}$ during ischemic arrest. In addition, hyperkalemic $\left(\mathrm{Ca}^{2+}\right.$-free $)$ cardioplegic solution caused increases in $\left[\mathrm{Ca}^{2+}\right]_{\mathrm{i}}$ at either $4^{\circ} \mathrm{C}$ or $37^{\circ} \mathrm{C}$, but hypothermia abolished the vascular contraction associated with microvascular exposure to hyperkalemia. The increase in $\left[\mathrm{Ca}^{2+}\right]_{\mathrm{i}}$ and the vascular contraction were also abolished when $\mathrm{Mg}^{2+}$ was added to the hyperkalemic cardioplegic solution and were increased when $\mathrm{Ca}^{2+}$ was added to the solution. These findings have implications regarding the

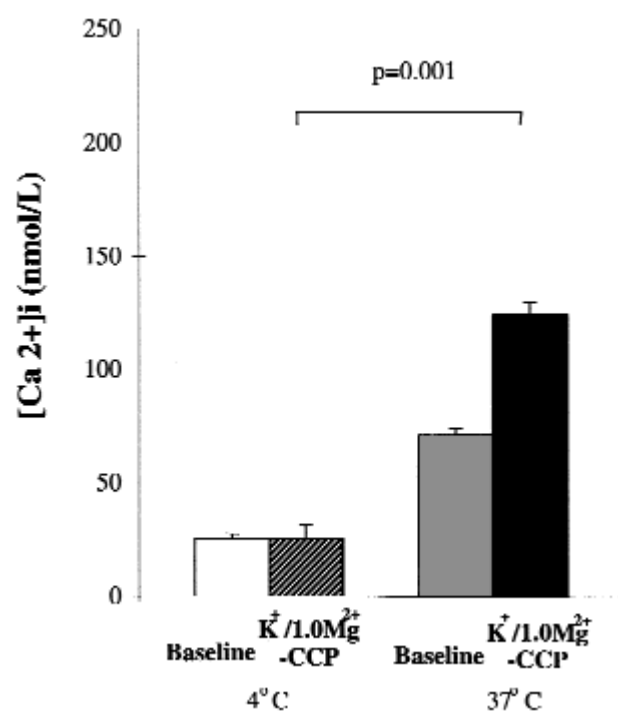

Fig 8. Increase from baseline in coronary smooth muscle intracellular free calcium concentration $\left(\left[\mathrm{Ca}^{2+}\right]_{i}\right)$ in response to application of calcium-free hyperkalemic $1.0 \mathrm{mmol} / \mathrm{L}$ magnesium crystalloid cardioplegic solution $\left(\mathrm{K}^{+} / 1.0 \mathrm{Mg}^{2+}\right.$ $C C P$ ) at $4^{\circ} \mathrm{C}$ and $37^{\circ} \mathrm{C}$ in nonischemic microvessels. Boxes represent mean; error bars indicate $\mathrm{SD} ; \mathrm{n}=4$ to 5 for each group. 
distribution of cardioplegic solution and the vascular resistance during infusion. In addition, changes in $\left[\mathrm{Ca}^{2+}\right]_{\mathrm{i}}$ may lead to altered vascular regulation mediated through pathways dependent on calcium movements within the cell. . $^{1,2,4}$

It is interesting to note that there was an apparent discrepancy between the baseline $\left[\mathrm{Ca}^{2+}\right]_{\mathrm{i}}$ and the observed $\mathrm{KCl}-$ induced increases in $\left[\mathrm{Ca}^{2+}\right]_{\mathrm{i}}$ and vascular contractions. In other words, baseline $\left[\mathrm{Ca}^{2+}\right]_{\mathrm{i}}$ was increased, but $\mathrm{KCl}$-induced contraction and increase in $\left[\mathrm{Ca}^{2+}\right]_{\mathrm{i}}$ were similar in all experimental groups. Thus acute changes in baseline vascular smooth muscle $\left[\mathrm{Ca}^{2+}\right]_{\mathrm{i}}$ may not significantly affect vasomotor tone or contractile responses. However, only a purely calcium-dependent contractile agonist $(\mathrm{KCl})$ was examined. Responses of microvessels to calcium-independent agonists may not be preserved, and calcium-dependent vasodilator mechanisms are known to be altered..$^{2,4}$

Calcium accumulation in coronary smooth muscle cells. Depolarization-induced $\mathrm{Ca}^{2+}$ influx through voltage-operated $\mathrm{Ca}^{2+}$ channels, $\mathrm{Ca}^{2+}$-induced $\mathrm{Ca}^{2+}$ release from the sarcoplasmic reticulum, and $\mathrm{Na}^{+} / \mathrm{Ca}^{2+}$ exchange mechanisms are 3 major potential causes of $\mathrm{Ca}^{2+}$ accumulation during cardioplegic infusion. However, the exact cause of accumulation is controversial and dependent on the cell type, $, 6,7$ age, ${ }^{8}$ species, and other factors. According to the Nernst equation, ${ }^{9,10}$ the open probability of voltage-operated $\mathrm{Ca}^{2+}$ channels is low during hyperkalemic $\left(25 \mathrm{mmol} / \mathrm{L} \mathrm{K}^{+}\right)$cardioplegic infusion, and maintained depolarization theoretically inhibits $\mathrm{Ca}^{2+}$ influx by inactivation of L-type $\mathrm{Ca}^{2+}$ channels. ${ }^{11,12}$ However, it has been reported that the increase in $\left[\mathrm{Ca}^{2+}\right]_{\mathrm{i}}$ during cardioplegic infusion may be inhibited by a calcium-channel blocker. ${ }^{7} \mathrm{~A}$ contribution of $\mathrm{Ca}^{2+}$ in the sarcoplasmic reticulum to $\left[\mathrm{Ca}^{2+}\right]_{\mathrm{i}}$ accumulation is both probable and predicted, ${ }^{13}$ but researchers have reported variable findings. ${ }^{6,7}$ Furthermore, increased intracellular free $\mathrm{Na}^{+}$as a result of $\mathrm{Na}^{+} / \mathrm{H}^{+}$exchange and depolarization of the membrane by hyperkalemic cardioplegic infusion can increase $\mathrm{Ca}^{2+}$ influx through the $\mathrm{Na}^{+} / \mathrm{Ca}^{2+}$ exchange system. ${ }^{14}$ Decreased activity of the $\mathrm{Na}^{+} / \mathrm{Ca}^{2+}$ exchange mechanism during cardioplegic infusion may theoretically account for some of the increase in $\left[\mathrm{Ca}^{2+}\right]_{i}{ }^{15}$

In this study the cold blood cardioplegic solution used contained less than $1.0 \mathrm{mmol} / \mathrm{L} \mathrm{Ca}^{2+}$ and $0.5 \mathrm{mmol} / \mathrm{L}$ $\mathrm{Mg}^{2+}$. This combination may cause a slight increase in $\left[\mathrm{Ca}^{2+}\right]_{\mathrm{i}}$ because it contains an inadequate concentration of the $\mathrm{Mg}^{2+}$ necessary to inhibit the increase in $\left[\mathrm{Ca}^{2+}\right]_{\mathrm{i}}$ (Fig 8). Also, it is likely that the extracellular free $\mathrm{Ca}^{2+}$ concentration $\left(\left[\mathrm{Ca}^{2+}\right]_{\mathrm{ex}}\right)$ in part determines the degree of $\mathrm{Ca}^{2+}$ influx in response to a hyperkalemic environment.
Changes in myocardial $\left[\mathrm{Ca}^{2+}\right]_{\mathrm{i}}$ during cardioplegic infusion have been reported to be minimal in the absence of extracellular $\mathrm{Ca}^{2+} .8,9$ In this study of vascular smooth muscle, however, we observed an increase in $\left[\mathrm{Ca}^{2+}\right]_{i}$ during exposure of microvessels to a $\mathrm{Ca}^{2+}$-free hyperkalemic solution. These findings suggest a contribution of $\mathrm{Ca}^{2+}$ influx through release of $\mathrm{Ca}^{2+}$ from intracellular stores (sarcoplasmic reticulum) and $\mathrm{Ca}^{2+}$-induced $\mathrm{Ca}^{2+}$ release to add to the $\left[\mathrm{Ca}^{2+}\right]_{\mathrm{i}}$ during cardioplegic infusion. A significant defect in sarcoplasmic reticulum $\mathrm{Ca}^{2+}$ transport in the early phase of ischemia has been reported; this is characterized by a depression of $\mathrm{Ca}^{2+}$ uptake and $\mathrm{Ca}^{2+}$ channel ATPase activity. ${ }^{16}$ The use of $\mathrm{Mg}^{2+}$ cold crystalloid cardioplegic solution completely abolished the increase in $\left[\mathrm{Ca}^{2+}\right]_{\mathrm{i}}$, possibly as a result of $\mathrm{Ca}-\mathrm{Mg}$ antagonism.

Hypothermia itself has been reported to augment the extent of depolarization, and this may lead to increased $\mathrm{Ca}^{2+}$ influx. ${ }^{17-19}$ Cold hyperkalemic cardioplegic infusion tends to induce more $\left[\mathrm{Ca}^{2+}\right]_{\mathrm{i}}$ overload than does infusion of a warm $\left(37^{\circ} \mathrm{C}\right)$ crystalloid solution. ${ }^{20,21} \mathrm{In}$ our study in nonischemic vessels, however, the difference in $\left[\mathrm{Ca}^{2+}\right]_{\mathrm{i}}$ accumulation between $4^{\circ} \mathrm{C}$ and $37^{\circ} \mathrm{C}$ during cardioplegic infusion was minimal but the increase in $\left[\mathrm{Ca}^{2+}\right]_{i}$ remained elevated in the cytoplasm after washing with Krebs buffer solution, suggesting that impaired calcium mobilization may persist for a more prolonged time.

Although the movement of $\mathrm{Mg}^{2+}$ across the sarcolemmal membrane tends to be slow, intracellular free $\mathrm{Mg}^{2+}$ may double within 1 to 2 seconds after a sudden challenge with increased extracellular free $\mathrm{Mg}^{2+} .{ }^{22}$ Increased extracellular $\mathrm{Mg}^{2+}$ has been reported to block $\mathrm{Ca}^{2+}$ channel currents ${ }^{23-25}$ and to act extracellularly by inhibiting $\mathrm{Ca}^{2+}$ influx through voltage-operated $\mathrm{Ca}^{2+}$ channels and intracellularly by blocking the movement of $\mathrm{Ca}^{2+}$ from the sarcoplasmic reticulum to the cytosol. ${ }^{13,25} \mathrm{Mg}^{2+}$ may also increase sarcoplasmic and mitochondrial uptakes of calcium. ${ }^{26}$ In fact, both $\mathrm{Mg}^{2+}$ cardioplegic infusion and $\mathrm{K}^{+} / \mathrm{Mg}^{2+}$ cardioplegic infusion have been reported to significantly reduce $\left[\mathrm{Ca}^{2+}\right]_{i}$ and provide enhanced myocardial functional recovery after ischemia. $6,13,27-29$

Limitations. The fact that fura 2 was loaded after rather than before ischemic cardioplegic infusion in isolated hearts may be a source of criticism. However, this was the only method available to examine the effects of blood on $\left[\mathrm{Ca}^{2+}\right]_{\mathrm{i}}$ during blood cardioplegic infusion. Because the data from $\mathrm{K}^{+}-$and $\mathrm{Mg}^{2+}$-cold crystalloid cardioplegic infusion in ischemic and nonischemic groups were very consistent and reproducible, we consider the data on blood cardioplegic 
infusion to be validated and credible. It should be noted that measurements of $\left[\mathrm{Ca}^{2+}\right]_{\mathrm{i}}$ and $\mathrm{KCl}$-induced vascular contraction were obtained after a period of equilibration in normothermic Krebs buffer solution and loading of fura 2. Thus these values may be underestimates of the actual effect in vivo.

Hypothermia $\left(4^{\circ} \mathrm{C}\right)$ in this study decreased the fluorescent ratio significantly $(P=.002)$ by $7.3 \% \pm 4.0 \%$ with respect to that seen under normothermic conditions $\left(37^{\circ} \mathrm{C}\right)$, suggesting that hypothermia reduced $\left[\mathrm{Ca}^{2+}\right]_{\mathrm{i}}$. In fact, calculation of the absolute $\left[\mathrm{Ca}^{2+}\right]_{\mathrm{i}}$ at baseline revealed that the $\left[\mathrm{Ca}^{2+}\right]_{\mathrm{i}}$ tended to be lower at $4^{\circ} \mathrm{C}$. Although a $\mathrm{K}_{\mathrm{d}}$ value at $4^{\circ} \mathrm{C}$ was not examined, the $\mathrm{K}_{\mathrm{d}}$ value at $37^{\circ} \mathrm{C}$ according to the report by Pawlowski and associates ${ }^{30}$ would be expected and was therefore used in this study. $\mathrm{R}_{\max }\left(0.983 \pm 0.009\right.$ at $4^{\circ} \mathrm{C}$ and 1.015 \pm 0.038 at $\left.37^{\circ} \mathrm{C}\right)$ and $\mathrm{R}_{\min }\left(0.412 \pm 0.010\right.$ at $4^{\circ} \mathrm{C}$ and $0.417 \pm 0.024$ at $37^{\circ} \mathrm{C}$ ) were not significantly different between $4^{\circ} \mathrm{C}$ and $37^{\circ} \mathrm{C}$, but the $\mathrm{S}$ value at $4{ }^{\circ} \mathrm{C}(1.11 \pm$ $0.07)$ was significantly $(P=.002)$ lower than that at $37^{\circ} \mathrm{C}(1.65 \pm 0.19)$. This finding suggests that, contrary to the previous reports, ${ }^{17-19}$ hypothermia itself may decrease $\left[\mathrm{Ca}^{2+}\right]_{\mathrm{i}}$. However, further examination is required to verify this speculation.

\section{Conclusions}

Cold hyperkalemic cardioplegic infusion led to an increase in $\left[\mathrm{Ca}^{2+}\right]_{i}$ in the coronary vascular smooth muscle similar to that observed during cold unprotected ischemia. The addition of $\mathrm{Mg}^{2+}$ to the hyperkalemic solution and the use of a blood-based or $\mathrm{Mg}^{2+}$-based cardioplegic solution both markedly reduced this increase in $\left[\mathrm{Ca}^{2+}\right]_{\mathrm{i}}$. Such solutions may better protect the coronary circulation during ischemic arrest.

\section{REFERENCES}

1. Wang SY, Friedman M, Franklin A, Sellke FW. Myogenic reactivity of coronary resistance arteries after cardiopulmonary bypass and hyperkalemic cardioplegia. Circulation 1995;92:1590-6.

2. Tofukuji M, Stamler A, Li J, Franklin A, Wang SY, Hariawala $\mathrm{MD}$, et al. Effects of magnesium cardioplegia on regulation of the porcine coronary circulation. J Surg Res 1997;69:233-9.

3. Wang SY, Friedman M, Johnson RG, Zeind AJ, Sellke FW. Adenosine triphosphate-sensitive $\mathrm{K}^{+}$channels mediate postcardioplegia coronary hyperemia. J Thorac Cardiovasc Surg 1995; 110:1073-82

4. Wang SY, Stamler A, Tofukuji M, Deuson TE, Sellke FW. Effect of blood and crystalloid cardioplegia on adrenergic and myogenic vascular mechanisms. Ann Thorac Surg 1997;63:41-9.

5. Meininger GA, Zawieja DC, Falcone JC, Hill MA, Davey JP. Calcium measurement in isolated arterioles during myogenic and agonist stimulation. Am J Physiol 1991;261:H950-9.

6. Ahn DS, Lee YH, Kang DH, Kang BS. Effect of hypothermic cardioplegia on cardiac protection. I. Effect of hypothermic car- dioplegia on the cytosolic $\mathrm{Ca}^{2+}$ concentration in rat ventricular myocytes. Yonsei Med J 1994;35:162-76.

7. Lee YH, Choi GB, Ahn DS, Kang BS. Changes in intracellular $\mathrm{Ca}^{2+}$ concentration of rabbit coronary artery smooth muscle cell during ischemic cardioplegia period. Yonsei Med J 1996;37:25161.

8. Cyran SE, Phillips J, Ditty S, Baylen BG, Cheung J, LaNoue K. Developmental differences in cardiac myocyte calcium homeostasis after steady-state potassium depolarization: mechanisms and implications for cardioplegia. J Pediatr 1993;122:S77-83.

9. Hill B. Equilibrium potentials and the Nernst equation. In: Hill B, editor. Ionic channels of excitable membranes. Sunderland (MA): Sinauer; 1984. p. 10-4.

10. Page E. The electrical potential difference across the cell membrane of heart muscle: biophysical considerations. Circulation 1962;26:582-95.

11. Nelson MT, Patlak JB, Worley JF, Standen NB. Calcium channels, potassium channels, and voltage dependence of arterial smooth muscle tone. Am J Physiol 1990;259:C3-18.

12. Pietrobon D, Hess P. Novel mechanism of voltage-dependent gating in L-type calcium channels. Nature 1990;346:651-5.

13. Tsukube T, McCully JD, Federman M, Krukenkamp IB, Levitsky S. Developmental differences in cytosolic calcium accumulation associated with surgically induced global ischemia: optimization of cardioplegic protection and mechanism of action. J Thorac Cardiovasc Surg 1996;112:175-84.

14. Wilde AA, Kleber AG. The combined effects of hypoxia, high $\mathrm{K}^{+}$, and acidosis on the intracellular sodium activity and resting potential in guinea pig papillary muscle. Cir Res 1986;58:249-56.

15. Cyran SE, Ditty SE, Baylen BG, Cheung J, LaNoue KF. Developmental differences in the response of cytosolic free calcium to potassium depolarization and cardioplegia in cardiac myocytes. J Mol Cell Cardiol 1992;24:1167-77.

16. Krause S, Hess L. Characterization of cardiac sarcoplasmic reticulum dysfunction during short-term, normothermic, global ischemia. Circ Res 1984;55:176-84.

17. Kurihara S, Sakai T. Effects of rapid cooling on mechanical and electrical responses in ventricular muscle of guinea-pig. J Physiol (Lond) 1985;361:361-78.

18. Bers DM, Bridge JH, Spitzer KW. Intracellular $\mathrm{Ca}^{2+}$ transient during rapid cooling contractures in guinea-pig ventricular myocytes. J Physiol (Lond) 1989;417:537-53.

19. Shattock MJ, Bers DM. Inotropic response to hypothermia and the temperature-dependence of ryanodine action in isolated rabbit and rat ventricular muscle: implications for excitation-contraction coupling. Circ Res 1987;61:761-71.

20. Liu X, Engelman RM, Rousou JA, Flack JE 3rd, Deaton DW, Das DK. Normothermic cardioplegia prevents intracellular calcium accumulation during cardioplegic arrest and reperfusion. Circulation 1994;90(Pt 2):II316-20.

21. Matsuda N, Tofukuji M, Morgan KG, Sellke FW. Coronary microvascular protection with magnesium: effects on intracellular calcium regulation and vascular function. Am J Physiol 1999;276:H1124-30.

22. Quamme GA, Dai LJ, Rabkin SW. Dynamics of intracellular free $\mathrm{Mg}^{2+}$ changes in a vascular smooth muscle cell line. Am J Physiol 1993;265:H281-8.

23. Campbell DL, Giles WR, Shibata EF. Ion transfer characteristics of the calcium current in bull-frog atrial myocytes. J Physiol (Lond) 1988;403:239-66.

24. Lansman JB, Hess P, Tsien RW. Blockade of current through sin- 
gle calcium channels by $\mathrm{Cd}^{2+}, \mathrm{Mg}^{2+}$, and $\mathrm{Ca}^{2+}$ : voltage and concentration dependence of calcium entry into the pore. $\mathrm{J}$ Gen Physiol 1986;88:321-47.

25. Meissner G, Henderson JS. Rapid calcium release from cardiac sarcoplasmic reticulum vesicles is dependent on $\mathrm{Ca}^{2+}$ and is modulated by $\mathrm{Mg}^{2+}$, adenine nucleotide, and calmodulin. J Biol Chem 1987;262:3065-73

26. Favaron M, Bernardi P. Tissue-specific modulation of the mitochondrial calcium uniporter by magnesium ions. FEBS Lett 1985;183:260-4.

27. Ataka K, Chen D, McCully J, Levitsky S, Feinberg H. Magnesium cardioplegia prevents accumulation of cytosolic cal- cium in the ischemic myocardium. J Mol Cell Cardiol 1993;25: 1387-90.

28. Tsukube T, McCully JD, Faulk EA, Federman M, LoCierco J 3rd, Krukenkamp IB, et al. Magnesium cardioplegia reduces cytosolic and nuclear calcium and DNA fragmentation in the senescent myocardium. Ann Thorac Surg 1994;58:1005-11.

29. Kronon M, Bolling KS, Allen BS, Rahman S, Wang T, Halldorsson A, et al. The relationship between calcium and magnesium in pediatric myocardial protection. J Thorac Cardiovasc Surg 1997;114:1010-9.

30. Pawloski J, Morgan KG. Mechanisms of intrinsic tone in ferret vascular smooth muscle. J Physiol (Lond) 1992;448:121-32.

\section{Online-www.aats.org}

Now you can get The Journal of Thoracic and Cardiovascular Surgery online. The Journal online brings you faster delivery time, easy searching of current and back issues, links to PubMed, AATS, WTSA and other important sites, and more. Visit the Journal online today. 